\section{P_301 縦隔悪性リンパ腫の臨床的検討}

徳島大学大学院病態制御外科学講座

鳥羽 博明, 近藤 和也, 吉田 光輝, 監崎 孝一郎, 三好 孝典, 先山 正二, 丹黑 章

【目的】縦隔悪性リンバ腫は, 胸腺腫や悪性肧細胞腫瘍などとの鑑別 が困難で, 増殖も速く, かつ治療方針が異なるため, 速やかな確定診 断が必要である. 我々は1991-2005年で17例の縦隔原発の悪性リンパ 腫を経験したので, 臨床病理学的に診断・治療に関して検討する。【患 者】男性 6 例，女性 11 例，平均年齢は 33 歳. non-Hodgkins が 11 例 で, T cell type が 6 例, B cell type が 7 例, Hodgkins は 3 例, MALT lymphpma が 2 例であった.【結果】腫場の位置は前縦隔が 14 例, 中 縦隔が 3 例であった。診断手技は経皮腫瘍針生検が 6 例, リンパ節生 検が 6 例, 腫瘍切除が 4 例, 骨髄穿刺が 1 例であった. 14 例の生検組 織は免疫染色検査にて診断した。経皮肺生検の 1 例は免疫染色検査で keratinが陽性であり, 胸腺腫として salvage surgeryを施行した。術後 に diffuse large cell lymphoma と診断された。腫瘍摘出術を施行した 2 例は術前に胸腺腫と診断され, 術後に MALT lymphpma と診断され た. lymphoblastic type の平均年齢は, diffuse large cell type と比較し て若年であった. MALT lymphoma 以外の15例はすべて化学療法が施 行された. lymphoblastic type $の 1$ 例は化学療法後に手術を施行した. MALT lymphoma の 2 例は外科的切除のみで生存中である.【考察】画 像上繀隔原発の悪性リンパ腫が疑われた症例は, 速やかに生検し, 免 疫染色検査にて診断すべきである。しかし，MALT lymphoma は多発 敝胞を伴った胸腺腫の陰影をとるため, 術前に診断することは困難で ある。

P-303

Von Recklinghausen 病を伴わない迷走神経発生 神経線維腫の一例

\section{大垣市民病院 呼吸器外科}

重光 希公生, 中村 彰太

Von Recklinghausen 病を伴わない迷走神経発生の神経線維腫という稀 な症例を経験したので報告する。患者は, 26 才, 男性. 健診での胸部 $\mathrm{X}$ 線写真にて絴隔腫瘍が疑われ当院へ紹介された，CT, MRI, 频部超 音波検査から, 腫瘍は甲状腺左葉下極から左 AP window まで薩摩芋状 に腫大しており，当初は紸隔甲状腺腫が疑われた，頸部横切開と第 4 肋間までの胸骨縦切開下に腫瘍摘除を行ったところ，迷走神経由来の 腫瘍であることが判明した。 腫瘍は完全摘除された。術後, 軽度嗄声 以外に問題は起きなかった。後日, 病理学的に神経線維腫と診断され た。

\section{P-302 縦隔腫瘍における FDG-PET 検査}

1 神戸市立中央市民病院 心臓血管外科, ${ }^{2}$ 神戸市立中央市民病院 呼 吸器外科

庄村 遊 ${ }^{1}$, 高橋 豊 ${ }^{2}$, 小松 輝也 ${ }^{2}$

【目的】 FDG-PET 検査 (PET 検査) の縦隔腫瘍に対する評価はまと まった報告は少ない，今回, 当科で経験した維隔腫瘍に対するPET検 查について報告する.【対象と方法】 2002 年 4 月より 2006 年 1 月まで に, PET 検查後に手術施行した縦隔腫瘍 5 症例を対象とした. PET 検 査では病変部位が集積像として認められるか否かを視鸴的に判断した。 【症例 1】51 歳女性. CT 検査で中縦隔囊胞性腫瘍, PET 検査では病 変部位の集積像を認めなかった. Tumor maker 異常值の無く, 腫崵切 除術施行. 病理診断は心膜囊腫であった。【症例 2】 31 歳女性. CT 検 査で前縦隔充実性腫瘍, PET 検査では病変部位の不均一な集積像を認 め,さらに縦隔や肺門リンパ節などにも散在する集積がみられた。 Tumor maker 異常值の無く, リンパ腫を疑い生検術施行. ホジキン病 であった.【症例 3】45歳男性. CT 検查で前縦隔充実性腫瘍, PET 検 査では病変部位の集積像を認めた。腫瘍切除術施行，胸腺腫であった。 【症例 4】40 歳女性. CT 検査で中縦隔囊胞性腫瘍, PET 検查では病 変部位の集積像を認めず，Tumor maker は異常值 (CEA $14.1 \mathrm{ng} / \mathrm{m} l$, SCC $1.6 \mathrm{ng} / \mathrm{m} l, C A 19-9169 \mathrm{U} / \mathrm{m} l)$ を示した。腫瘍切除術施行. 成熟 奇形腫であった。症例 5】70 歳男性. CT 検査で後縦隔充実性腫瘍, PET 検査では病変部位の集積像を認めなかった. Tumor maker 異常 值の無く, 腫瘍切除術施行. 神経鞘腫であった.【結語】当科で経験し た縦隔腫瘍に対するPET検査を示したが, 集積像の無い3例はすべて 良性腫瘍であった。PET 検査は糖代謝の充進部位を示すことができ る機能画像検査であり, 縦隔腫痬においても術前診断に役立つことが 示唆された。

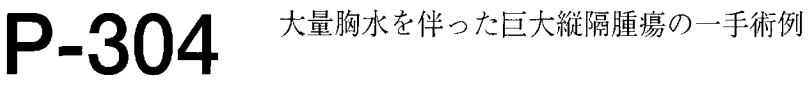

1 新潟県立中央病院, ${ }^{2}$ 杏林大学 医学部 外科

有村 隆明 ${ }^{1}$, 篠原 博彦 ${ }^{1}$, 矢沢 正知 ${ }^{1}$, 谷屋 朝幸 ${ }^{2}$

症例は 20 歳女性. 2005 年 5 月に正常分娩. 2005 年 7 月上旬感冒様症 状で近医受診。内服治療を受けるも改善なく 7 月下旬に胸部 X線写真 施行された，胸部X線写真で左大量胸水の貯留があり当科紹介された. 初診時胸部 X 線写真では左胸腔の大量胸水のため縦隔は右方に偏移, 左肺の含気は全く認められなかった．胸部 CT では左肺が完全に虚脱 し，縦隔後面に径 $80 \mathrm{~mm}$ 大の巨大縦隔腫瘍が認められた。 入院後直ち に胸腔ドレーンを扦人し計 $4000 \mathrm{ml}$ のドレナージが行えた。胸水細胞 診ではClassIVで腺癌が疑われたが，CT, MRIの画像所見や腫瘍マー カーは悪性所見に之しく, 確定診断目的にCTガイド下針生検を施行 した。組織診にて神経鞘腫との診断を得たため開胸下縦隔腫瘍摘出術 を施行した。腫瘍は䅠隔から胸腔内に突出していたが脊椎管内への進 展や椎体への癒着は認められず，比較的容易に腫瘍摘出が行えた。摘 出標本での組織診断も神経鞘腫であり悪性像は認められなかった。術 後経過は良好で現在まで再発は認めていない，大量胸水を伴った神経 鞘腫の報告例は稀であり，若干の文献的考察を加えて報告市る。 